\title{
ANALISIS COST SHARING (BIAYA TAMBAHAN) PASIEN BPJS DI RUMAH SAKIT PASAR WAJO BUTON PROVINSI SULAWESI TENGGARA
}

\section{Analysis Of Cost Sharing (Additional Cost) BPJS Patients at Pasar wajo Hospital Buton in Southeast Sulawesi}

\author{
Maryono Dassi, Hardi K \\ Universitas Indonesia Timur \\ yhondassi@yahoo.com
}

\begin{abstract}
ABSTRAK
Biaya tambahan (Cost Sharing) adalah biaya yang harus dibayar oleh pasien peserta BPS karena mendapat pelayanan kesehatan di Rumah Sakit yang diperoleh dari pengurangan besarnya tarif dengan besarnya biaya yang ditanggung oleh BPJS. Biaya tambahan tersebut adalah biaya obat-obatan yang tidak masuk dalam (DPHO), pelayanan medis dan menempati kelas perawatan yang tidak sesuai dengan golongannya. Tujuan penelitian ini adalah untuk mengetahui besarnya biaya tambahan 2017 berdasarkan kelas perawatan, biaya obat dan biaya pelayanan. Jenis penelitian ini adalah penelitian observasional dengan pendekatan deskriptif. pengambilan sampel dilakukan dengan cara mengambil data dari rekam medik Rumah Sakit dan melakukan proses wawancara dengan petugas kesehatan Rumah Sakit. Hasil penelitian menunjukkan bahwa Besaranya biaya tambahan pasien BPJS di Rumah Sakit kabupaten buton sebesar Rp.795,000,- , berdasarkan golongan/kepangkatan. Biaya tambahan Rumah Sakit Kabupaten Butonl sebesar Rp.422,000,- Untuk biaya perawatan. Biaya tambahan pasien BPJS di Rumah Sakit Islam Kabupaten Butonl sebesar Rp.134,700,. Berdasarkan hasil penelitian tersebut, maka disarankan Perlunya BPJS dalam menetapkan kelas perawatan bagi peserta BPJS tidak hanya melihat dari golongannya tapi menetapkan suatu kebijakan dengan melihat penyakit tertentu yang memerlukan ketenangan dalam proses penyembuhan dan sebisa mungkin menyediakan obat-obatan yang dibutuhkan oleh pasien untuk mengurangi beban pasien.
\end{abstract}

\section{Kata Kunci : Cost Sharing, Pasien BPJS}

\begin{abstract}
Additional costs (Cost Sharing) are costs that must be paid by patients participating in BPS because they get health services at the hospital which are obtained from the reduction in the amount of the tariff with the amount of costs borne by the BPJS. These additional costs are the cost of drugs that are not included (DPHO), medical services and occupancy classes that are not in accordance with their class. The purpose of this study is to find out the size of 2017 additional costs based on treatment classes, drug costs and service fees. This type of research is an observational study with a descriptive approach. Sampling is done by retrieving data from the hospital medical record and conducting the interview process with the hospital health officer. The results showed that the amount of the additional cost of BPJS patients at Buton District Hospital was Rp.795,000, based on class / rank. The additional cost of Butonl District Hospital is Rp.422,000, - for maintenance costs. Additional costs for BPJS patients at Butonl District Islamic Hospital amounted to Rp.134,700 ,. Based on the results of these studies, it is recommended that the need for BPJS in establishing treatment classes for BPJS participants not only see from their class but establish a policy by looking at certain diseases that require
\end{abstract}


calmness in the healing process and as much as possible providing medicines needed by patients to reduce patient burden .

\section{Keywords: Cost Sharing, BPJS's Patients}

\section{PENDAHULUAN}

Masalah pembiayaan kesehatan, pada akhir-akhir ini banyak di keluhkan masyarakat. Mereka mengeluh, oleh karena sakit menjadi mahal. Semakin meningkatnya biaya pelayanan kesehatan dapat disebabkan karena terjadinya asymmetry of information antara pemberi pelayanan kesehatan dengan orang yang membutuhkan pelayanan kesehatan. Sehingga masyarakat cendrung menerima apa saja yang disarankan oleh pemberi pelayanan kesehatan. Selain itu faktor yang mempengaruhi semakin mahalnya biaya kesehatan adalah, teknologi kedokteran yang semakin canggih, dibutuhkannya sumber daya manusia yang banyak dalam menunjang infrastruktur kesehatan. (Prita cipta, 2011)

Biaya pelayanan Rumah Sakit di Indonesia secara umum merupakan masalah yang kompleks yang banyak kendala dimana dapat kita lihat publikasi informasi biaya sering tidak jelas. Pada Rumah Sakit Pemerintah khususnya mengenai alokasi anggaran masih belum cukup memadai hal ini disebabkan antara lain karena biaya yang harus ditanggung oleh Rumah Sakit terutama biaya peralatan, biaya operasional dan pemeliharaan kelihatannya cenderung meningkat mengikuti kemajuan teknologi kesehatan yang semakin canggih (Aditama, Tjandra Yoga.2002).

Teknologi maju dan persaingan Global mempunyai pengaruh yang besar pada berbagai Organisasi termasuk Rumah Sakit, yang telah mengubah secara dramatis pola-pola perilaku biaya. Perubahan secara radikal maupun berkelanjutan dari manajemen tradisional ke sistem manajemen kontemporer harus segera dilakukan di Rumah Sakit (Asrianty, 2004).

Adanya system restitusi pada dasarnya sangat memberatkan anggaran Pemerintah, maka pada waktu itu di jejaki berbagai kemungkinan penerapan cara lain untuk membiayai pemeliharaan kesehatan bagi Pegawai, penerima Pensiun dan anggota keluarganya. Pada tahun 1968 yang mengatur hak dan kewajiban peserta yang disertai dengan pembatasanpembatasan. Dalam pembiayaan Pegawai, gaji mereka dipotong $2 \%$ sebagai dana praupaya pemeliharaan kesehatan, sedangkan administrasinya dilakukan oleh suatu Badan Khusus yang ditunjuk Departemen Kesehatan dalam hal ini Badan Penyelenggara Jaminan Sosial atau BPJS.

Selama ini biaya Rumah Sakit diatur dengan Peraturan Daerah (PERDA). Peraturan Daerah tersebut memuat penetapan biaya pelayanan tindakan bagian bedah dengan biaya yang bervariasi/tingkatan golongan yakni operasi kecil, sedang dan besar tanpa memperhitungkan biaya real, yang sebenarnya dikeluarkan oleh Rumah Sakit (Astuti, Sri, S.2007).

Persaingan yang ada saat ini menuntut Rumah Sakit untuk menerapkan konsep-konsep manajemen modern seperti layaknya organisasi bisnis sehingga memungkinkan Organisasi Rumah Sakit menjadi organisasi bisnis yang cost effective, dengan tanpa meninggalkan mutu dan fungsi sosial yang diembangnya. Organisasi Rumah Sakit harus mampu memberikan jasa pelayanan yang sesuai dengan kebutuhan dan keinginan pasien dan calon pasien. Jasa pelayanan yang diberikan harus bermutu, penanganan pasien lebih cepat harga relatif lebih murah dan bermanfaat (Azwar, Azrul.1996).

Untuk lebih meningkatkan pelayanan,tahun 1984 di keluarkan PP.NO.22/1984 tentang hak-hak peserta BPJS berupa: pemeriksaan lainnya untuk menegakkan diagnose, tindakan gawat darurat dan tindakan lain untuk penyembuhan, prothese gigi dan prothese lainnya, Keluarga Berencana, Kesegaran Jasmani dan kegiatan untuk penyembuhan (Astuti, Sri, S.2007). 
Peraturan pemerintah UU No 40 Tahun 2004 tentang jaminan sosial nasionan(SJSN) Indonesia yang dalam hal ini bertanggung jawab atas peningkatan pelayanan kesehatan bagi Pegawai Negeri Sipil dan anggota keluarganya serta perluasan kepesertaan BPJS tidak mempunyai fasilitas kesehatan sendiri-sendiri.

Meningkatnya mutu pelayanan khususnya bagi pasien peserta BPJS Indonesia akan membawa keuntungan yaitu meningkatnya kepuasan pasien dan harapan-harapan pasien, kesetiaan pasien dan meningkatnya citra rumah sakit. Bagi pasien, kepuasan terhadap suatu pelayanan rumah sakit yang baik dengan kesembuhan dari penyakit, meningkatnya derajat kesehatan, kecepatan pelayanan, kepuasan lingkgan fisik, dan tarif yang memadai.

Hasil Susenas 1995 dan 1998 menunjukkan bahwa antara tahun 1995 dan 1998 telah terjadi pergeseran pilihan fasilitas pelayanan rawat jalan dari PPK jaringan PPK ke PPK nonjaringan.

Pada tahun 1996 ditetapkan cost-sharing bagi pelayanan rawat inap dikelas II dan I, selanjutnya pada tahun 2014 diberlakukan cost-sharing bagi semua peserta yang menggunakan pelayanan Rumah Sakit, baik untuk rawat jalan maupun untuk rawat inap. Untuk itu secara teori, cara penetapan premi proporsional terhadap pendapatan (5\% dari gaji pokok) lebih adil dibanding dengan risk based premium, namun karena take home pay pegawai golongan I dan II lebih besar dari golongan III dan IV.

Retribusi Pelayanan Kesehatan yang telah ditetapkan di Rumah Sakit Pasar Wajo Buton juga berbeda-beda. Untuk kelas VIP Rp.285.000,-/hari, kelas I Rp.113.000,-/hari, kelas II Rp.80.000,-/hari. Sedangkan besarnya tarif pelayanan kesehatan di Rumah Sakit bagi peserta BPJS kelas I Rp.56.500,-/hari, kelas II Rp.40.000,-/hari.

\section{METODE PENELITIAN}

Penelitian ini dilakukan di Unit Rawat Inap Rumah Sakit Pasar Wajo Buton pada bulan April tahun 2017. Populasi dalam penelitian ini adalah semua laporan keuangan pasien peserta BPJS yang telah di rawat inap Rumah Sakit Pasar Wajo Buton tahun 2017. Sampel dalam penelitian ini adalah semua laporan keuangan pasien peserta BPJS Sosial yang dirawat inap di Rumah Sakit Pasar Wajo Buton yang diambil secara total biaya tambahan selama bulan april.

Jenis penelitian yang digunakan adalah penelitian survey dengan pendekatan Deskriptif, dengan tujuan untuk memperoleh informasi tentang biaya cost sharing pelayanan kesehatan di unit rawat inap Rumah Sakit Pasar Wajo Buton tahun 2017.

Pengumpulan data dilakukan dengan dua cara, yakni data primer melalui wawancara dengan petugas kesehatan dan mengambil data melalui data sekunder dari rekam medic dan data sekunder diperoleh dari Rumah Sakit serta sumber lain yang terkait atau berhubungan dengan penelitian ini misalnya jurnal dan buku-buku penunjang lainnya. 
HASIL

Biaya tambahan dari segi golongan /kepangkatan pada Rumah Sakit Pasar

Tabel 1.

Biaya tambahan dari segi golongan/kepangkatan pada Unit rawat Inap

Pasien di Rumah Sakit Pasar Wajo Buton

\begin{tabular}{|c|c|c|r|}
\hline $\begin{array}{c}\text { Golongan dan } \\
\text { kelas perawatan }\end{array}$ & $\begin{array}{c}\text { Biaya } \\
\text { kamar }\end{array}$ & $\begin{array}{c}\text { Tanggungan } \\
\text { BPJS }\end{array}$ & $\begin{array}{c}\text { Cost } \\
\text { Sharing }\end{array}$ \\
\hline Gol 2 kelas 1 & $200,000,-$ & $175,000,--$ & $25,000,-$ \\
Gol 3 kelas VIP B & $360,000,-$ & $200,000,-$ & $160,000,-$ \\
Gol 4 kelas VIP A & $350,000,-$ & $200,000,--$ & $150,000,-$ \\
Gol 4 kelas VIP A & $350,000,-$ & $200,000,-$ & $150,000,-$ \\
Gol 4 kelas VIP B & $360,000,-$ & $200,000,-$ & $160,000,-$ \\
Gol 4 kelas VIP B & $350,000,-$ & $200,000,-$ & $150,000,-$ \\
\hline \multicolumn{2}{|c|}{ total Cost Sharing } & $795,000,-$ \\
\hline
\end{tabular}

Tabel 1 menunjukkan bahwa dari peserta BPJS pasien rawat inap Rumah Sakit Pasar Wajo Buton pada bulan Mei 2015 biaya Cost Sharing tertinggi terdapat pada golongan 4 kelas VIP A sebesar Rp. 160.000,-, dan terendah terdapat pada golongan 2 kelas 2 sebesar Rp. 25,000 .

\section{Biaya tambahan dari segi jenis tindakan pada Rumah Sakit Pasar}

Tabel 2.

Biaya tambahan dari segi jenis tindakan pada Unit rawat Inap

Pasien di Rumah Sakit Pasar Wajo Buton

\begin{tabular}{|l|c|c|c|}
\hline Jenis Tindakan & Biaya Rumah Sakit & Tanggungan BPJS & Cost Sharing \\
\hline Anestesi & 246,500 & 246,500 & - \\
Laboratorium & 272,000 & 122,000 & 150,000 \\
Radiologi & 100,000 & 53,000 & 47,000 \\
Iccu & 660,000 & 660,000 & - \\
Fisioterapi & 525,000 & 300,000 & 225,000 \\
\hline \multicolumn{2}{|c|}{ total Cost Sharing } \\
\hline
\end{tabular}

Tabel 2 menunjukkan bahwa dari peserta BPJS pasien rawat inap Rumah Sakit Pasar Wajo Buton pada bulan Mei 2015 biaya Cost Sharing tertinggi terdapat pada jenis pelayanan tindakan fisioterapi sebesar Rp. 225.000,-, dan terendah terdapat pada tindakan radiologi sebesar Rp. 47,000,-. 
Biaya tambahan dari segi jenis pelayanan obat pada Rumah Sakit Pasar

Tabel 3

Biaya tambahan dari segi jenis pelayanan obat pada Unit rawat Inap

Pasien di Rumah Sakit Pasar Wajo Buton

\begin{tabular}{|c|c|c|}
\hline Biaya Obat & tanggungan BPJS & Cost Sharing \\
\hline 135,000 & 135,000 & - \\
125,400 & 110,000 & 15,400 \\
235,000 & 235,000 & - \\
348,000 & 327,000 & 21,000 \\
127,500 & 105,000 & 22,500 \\
162,700 & 150,400 & 12,300 \\
198,200 & 175,000 & 23,200 \\
126,600 & 126,600 & - \\
213,500 & 202,500 & 11,000 \\
112,400 & 102,300 & 10,100 \\
152,300 & 143,200 & 9,100 \\
76,400 & 74,300 & 2,100 \\
89,400 & 86,300 & 3,100 \\
64,800 & 59,900 & 4,900 \\
127,800 & 127,800 & - \\
\multicolumn{2}{|c|}{ Total Cost Sharing } \\
\hline \multicolumn{2}{|c|}{} \\
Sumber: Data Sekunder, 2017
\end{tabular}

Tabel 3 menunjukkan bahwa dari peserta BPJS pasien rawat inap Rumah Sakit Pasar Wajo Buton pada bulan Mei 2015 biaya Cost Sharing tertinggi terdapat pada pasien ke-7 sebesar Rp. 23,200,-, dan terendah terdapat pada pasie ke-12 sebesar Rp. 2,100,-.

\section{PEMBAHASAN}

Cost Sharing atau kelebihan biaya menurut Peraturan BPJS No. 1 Tahun 2014 pasal 326 ayat 1, tentang Pemeliharaan Kesehatan Pegawai Negeri Sipil, Veteran, Perintis Kemerdekaan beserta keluarganya, bahwa yang dimaksud dengan bayar biaya tambahan atau kelebihan biaya yang menjadi tanggung jawab peserta adalah bila peserta mempergunakan sarana pemeliharaan kesehatan yang melebihi pelayanan kesehatan.

1. Pangkat/Golongan

Keberadaan BPJS selama ini merupakan salah satu jenis asuransi yang menjaminpelayanan kesehatan bagi para Pegawai Negeri Sipil (PNS), namun belum semua jenis pelayanan kesehatan dapat ditanggung oleh BPJS. Konsekuensi dari jenis pelayanan yang dapat diberikan tersebut membawa dampak pada peserta BPJS. Masih terdapatnya biaya tambahan (Cost Sharing) yang harus dibayar oleh pasien peserta BPJS. Ada beberapa factor yang dapat menjadi penyebab tingginya Cost Sharing tesebut, salah satunya golongan/kepangkatan yang berpengaruh terhadap besarnya biaya tambahan yang harus ditanggung oleh pasien rawat inap peserta BPJS.

Golongan/kepangkatan adalah kedudukan yang memungkinkan tingkat seseorang Pegawai Negeri Sipil dalam rangkaian susunan kepegawaian dan digunakan sebagai dasar penggajian (siagian, 1998).

Sedangkan retribusi Pelayanan Kesehatan yang telah ditetapkan di Rumah Sakit Pasar Wajo Buton juga berbeda-beda. Untuk kelas VIP Rp.350.000,-/hari, kelas I Rp.200.000,-/hari, kelas II Rp.175.000,-/hari. Sedangkan besarnya tarif pelayanan 
kesehatan di Rumah Sakit bagi peserta BPJS kelas I Rp.200.000,-/hari, kelas II Rp.175.000,-/hari.

Hasil penelitian menunjukkan bahwa biaya tambahan yang dikeluarkan oleh pasien BPJS Sosial di Rumah Sakit Pasar Wajo Buton dari segi golongan dan kelas perawatan lebih rendah sebanyak Rp. 795,000,- dibandingkan di RS Pelamonia Buton sebanyak Rp. 1,125,000,-. Ini menunjukkan bahwa biaya tambahan yang dikeluarkan oleh pasien BPJS Sosial di RS Pelamonia jauh lebih tinggi sebanyak Rp. 330,000,- dibandingkan RS Pasar Wajo.

Penelitian Safwan Yasir (2009) menunjukkan bahwa sebanyak 52,4\% pasien BPJS menempati kelas perawatan yang lebih baik dari pada yang seharusnya mereka terima.

Hasil penelitian ini dan penelitian sebelumnya menunjukkan bahwa pasien peserta BPJS cenderung untuk menggunakan kelas keperawatan yang lebih baik dari yang telah ditetapkan. Hal ini diakibatkan keingin pasien untuk mendapatkan pelayanan yang lebih baik.

2. Pelayanan Medis/ jenis tindakan

Pelayanan kesehatan adalah setiap upaya yang diselenggarakan sendiri atau secara bersama-sama dalam suatu organisasi untuk memelihara dan meningkatkan kesehatan, mencegah dan menyembuhkan penyakit serta memulihka kesehatan perseorangan, keluarga, kelompok dan masyarakat.

Berat atau ringannya pasien yang dirawat di Rumah Sakit sulit untuk diprediksikan, demikian pula Rumah Sakit tidak bisa memiliki pasien yang dirawat dengan alasan-alasan tertentu. Sehubungan dengan berate ringannya penyakit yang di rawat di Rumah Sakit, semakin berat penyakit yang diderita seseorang maka semakin kompleks pula pemeriksaan/tindakan medic yang akan dilakukan. Misalnya, pasien yang menderita penyakit stroke, penyakit ginjal dan lain-lainnya. Keadaan ini menimbulkan konsekuensi lain yaitu pengeluaran biaya yang lebih tinggi. Selain itu, berat ringannya keadaan penyakit memberikan konstribusi yang berbeda terhadap besarnya biaya satuan yang harus dikeluarkan perhari.

Hasil penelitian ini menunjukkan bahwa peserta BPJS selama ini lebih banyak mendapatkan bantuan pembiayaan dari segi tarif rawat inap, sedangkan obat dan tindakan medik masih belum memadai, sebab untuk tindakan medik tertentu jumlah (Rp) yang harus dibayar pasien jauh lebih besar dari yang ditanggung oleh PT. BPJS.

biaya Cost Sharing yang dikeluarkan oleh pasien BPJS Sosial di RS Pasar Wajo Buton dari segi jenis tindakan petugas kesehatan Rumah Sakit sebanyak Rp. 422,000,- Ini menunjukkan bahwa biaya tambahan yang dikeluarkan oleh pasien BPJS Sosial di Rumah Sakit Pelamonia jauh lebih tinggi sebanyak Rp. 115,000,- dibandingkan Rumah Sakit Pasar Wajo Buton.

3. Pelayanan Obat

Pelayanan obat adalah pemberian obat-obatan diluar obat standar yang termasuk dalam paket Rumah Sakit, yang diperlukan untuk pelayanan kesehatan sesuai dengan indikasi medis dan dengan Daftar Plafon Harga Obat (DPHO) yang digunakan bagi peserta dan keluarganyaoleh PT. BPJS sesuai surat keputusan Menteri Kesehatan. Adapun obat yang termasuk dalam Daftar Plafon Harga Obat (DPHO) bukanlah obat generik, akan tetapi obat yang dibutuhkan dapat diberikan dengan harga yang memenuhi daftar plafon tertentu.

Seleksi jenis obat dilakukan ahli farmakologi maupun klinis, selain itu juga dilakukan analisis dari aspek harga pembuatan DPHO yang mengacu pada daftar obat Esensial Nasional (DOEN) yang telah disusun oleh pemerintah. Hal ini dikarenakan obatobat yang ada dalam DOEN merupakan obat-obat pilihan yang paling dibutuhkan dan mutlak untuk diadakan. Beberapa jenis obat yang masuk dalam DOEN mulai dari antibiotik, 
anti inflimasi, anti depresi, anti hipertensi, anti jamur, obat asma, obat maag hingga obat kulit..

Hasil penelitian menunjukkan bahwa biaya tambahan yang dikeluarkan oleh pasien BPJS Sosial di RS Pasar Wajo Buton dari segi jenis pelayanan obat lebih rendah sebanyak Rp. 134,700,-. Ini menunjukkan bahwa biaya tambahan yang dikeluarkan oleh pasien BPJS Sosial di RS Pelamonia jauh lebih tinggi sebanyak Rp. 351,400,dibandingkan RS Pasar Wajo.

Hasil penelitian menunjukkan bahwa biaya obat adalah biaya yang harus ditanggung oleh pasien, yang berarti BPJS belum mampu menyedikan seluruh obat yang dibutuhkan oleh pasien sebagai suatu komponen utama pengobatan penyakit jika dibandingkan dengan komponen tarif rawat inap yang selama ini lebih dipentingkan oleh BPJS.

\section{KESIMPULAN DAN SARAN}

Besar Cost Sharing pasien BPJS Sosial berdasarkan Golongan /kepangkatan di unit rawat inap sebanyak Rp.795,000,- . Besar Cost Sharing pasien BPJS Sosial Untuk biaya perawatan dan pelayanan medis di unit rawat inap sebanyak Rp. 422,000,-, dan besar Cost Sharing pasien BPJS Sosial Untuk biaya pelayanan obat yang tidak masuk dalam DPHO di unit rawat inap sebesar Rp.134,700. Perlunya BPJS dalam menetapkan kelas perawatan bagi pasien peserta BPJS tidak hanya melihat dari segi golongannya tapi juga melihat jenis penyakit yang diderita yang memerlukan perawatan khusus dalam proses penyembuhan. BPJS diharapkan juga dapat menyediakan obat-obatan yang dibutuhkan oleh pasien untuk mengurangi beban pasien BPJS, dan pada pihak BPJS juga kiranya lebih jeli melihat penyebab dari tingginya animo masyarakat pengguna BPJS untuk berpindah kelas perawatan dari kelas perawatan yang memang menjadi haknya ke kelas perawatan yang lebih tinggi yang bukan haknya. Disarankan kepada peneliti selanjutnya dapat melanjutkan penelitian ini dengan mengamati variabel lain yang berhubungan dengan penelitian ini.

\section{DAFTAR PUSTAKA}

Aditama, Tjandra Yoga.2002. Manajemen Rumah Sakit. Universitas Indonesia Press

Asrianty, 2010. Analisis Besarnya Selisih Biaya Pasien Rawat Inap BPJS di RSU Labuang Baji

Tahun 2004. Skripsi tidak dipublikasikan Makassar. FKM UNHAS

Astuti, Sri, S.2007. Modul Pelatihan Perencanaan dan Penganggaran Kesehatan Terpadu (P2KT). Direktorat Jenderal Bina Kesehatan Masyarakat, Departemen Kesehatan RI.

Azwar, Azrul.1996. Program Menjaga Mutu Kasehatan, Pustaka Sinar Harapan. Jakarta

BPJS,2014. Daftar dan Plafon Harga Obat (DPHO), BPJS Indonesia , 1996. Pengantar Administrasi Kesehatan, Edisi ke 3, Jakarta.

Departemen Agama Republik Indonesia, 2005. Al Quran dan terjemahannya. PT. Syaamil Cipta Media. Bandung.

Depkes RI, 1991. PT. Asuransi Kesehatan Indonesia, Peraturan Pemerintah RI, No.69.

_ , 1999. Indonesia Sehat 2010 Visi Baru, Misi, Kebijakan dan Strategi Pembangunan Kesehatan. Jakarta.

, 2014. Keputusan Bersama Menteri Kesehatan dan Menteri Dalam Negeri RI, Tarif dan Tatalaksana Pelayanan Kesehatan di Rumah Sakit Bagi Peserta BPJS dan anggota Keluarganya.

BPJS Review Utilisasi Manajemen Klaim dan Fraud (Kecurangan Asuransi Kesehatan) 
Gani, A. 2000. Dasar-dasar Asuransi Kesehatan Bagian A. Pusat Kajian Ekonomi Kesehatan FKM UI, Depok.

Junaidi Arifin, 1989. Manajemen Organisasi Nirlaba, SEPMA ( Sekretariat Pengembangan Manajemen ), cetakan kedua, Jakarta.

Lumenta, 1989. Pelayanan Medis, Citra dan harapan Kanisius, Yogyakarta.

Murti Bisma, 2000. Dasar-dasar Asuransi. Jakarta Kanisius.

Noor, Noer Bahri, 2001. Admistrasi Rumah Sakit. Makassar.

Siagian, Sondang, 1989. Teori Motivasi dan Aplikasinya. Bina Aksara, Jakarta.

Sulastomo, 1997. Asuransi Kesehatan dan Managed Care. PT. Gramedia Pustaka Utama, cetakan kedua, Jakarta.

Thabrany, H. 2000. Asuransi Kesehatan, Edisi Pertama Pusat Kajian Ekonomi Kesehatan UI, Depok.

Tharany Hasbullah, 1999. Menuju Asuransi Kesehatan Nasional, Makalah Pada Kuliah Perdana, Universitas Indonesia, Depok Jakarta

Wijono Djoko, 1999. Manajemen Mutu Pelayanan Kesehatan Teori, Stretegi dan Aplikasi, Airlangga University Press, Surabaya. 